\title{
Hendersonia acicola in an epidemic caused by Lophodermella sulcigena with special reference to biological control
}

\author{
RISTO JALKANEN and RIITTA LAAKSO
}

\begin{abstract}
JALKANEN, R. \& LAAKSO, R. 1986: Hendersonia acicola in an epidemic caused by Lophodermella sulcigena with special reference to biological control. - Karstenia 26: 49-56.

The amount and role of Hendersonia acicola Tub. in the epidemic caused by Lophodermella sulcigena (Rostr.) v. Höhn. was followed on Scots pine (Pinus sylvestris L.) in Finland. From year to year $H$. acicola increased on needles primarily infected by $L$. sulcigena up to the end of the Lophodermella epidemic. Hendersonia was first abundant in the lower crown, while the upper parts were nearly free of it. The increase of $H$. acicola prevented $L$. sulcigena from producing ascocarps and led to the recovery of the trees and stands. L. sulcigena could fruit only in those needles which were free of $H$. acicola in the autumn. The autumnal presence of $H$. acicola in the needles led to a natural control of the pathogen. Experiments with $H$. acicola showed that it is possible to develop biological control against $L$. sulcigena.
\end{abstract}

Risto Jalkanen \& Riitta Laakso, The Finnish Forest Research Institute, Rovaniemi Research Station, P.O. Box 16, SF-96301 Rovaniemi, Finland

\section{Introduction}

Lophodermella sulcigena (Rostr.) v. Höhn. causes early death of current-year needles on Scots pine (Pinus sylvestris L.). Although the disease does not kill trees, an epidemic lasting for many years reduces tree growth significantly (Mitchell et al. 1976a, Jalkanen 1986b). To avoid unwanted growth losses, the epidemic should be restricted to no more than one or two years.

The infections of $L$. sulcigena can be prevented by chemical treatments (Millar 1970), which are labourious and expensive and may have adverse effects on nature. The spread of the disease can be controlled by felling the most severely diseased trees of the plantations, especially in the beginning of an epidemic (Lagerberg 1910). Hygiene is improved by burning the infected branches (Terrier 1944).

Indirect control often offers easy and cheap ways to avoid the disease. Resistance differences between progenies or clones (Lagerberg 1910, Jalkanen 1982) or even of single trees in small populations (RollHansen 1969) have revealed clues for diminishing the susceptibility of the Scots pine to L. sulcigena by resistance breeding (Terrier 1944, Roll-Hansen 1969). The susceptibility of Scots pine is diminished by avoiding planting in fertile soils, which are not its typical habitats (Jalkanen 1985).
A possible biological control might be the use of Hendersonia acicola Tub., a fungus which colonises only the needles infected by a Lophodermella species (Darker 1967). If $H$. acicola invades the needles already in the late summer, the fruiting of pathogenic Lophodermella seems to be prevented (Mitchell et al. 1976b).

In an earlier work, Jalkanen (1985) described the relationship between the autumnal colour and structure of the needles infected primarily by $L$. sulcigena and $H$. acicola. He also implied that the presence of $H$. acicola in the autumnal needles deleteriously affects the life cycle of the primary pathogen. In order to get a more detailed picture of the role of $\mathrm{H}$. acicola in the Lophodermella epidemic, the following issues were given special attention: 1) the distribution and abundance of $H$. acicola during a tree and stand level epidemic caused by Lophodermella, 2) the natural autumnal infestation of needles by $H$. acicola, and its effect on the ascocarp production of the pathogen, and 3 ) finding a method to control the disease, especially with the help of $H$. acicola.

We tentatively assume that 1$) \mathrm{H}$. acicola has a decisive role in the cessation of the Lophodermella epidemic in nature and 2) it is possible to use $H$. acicola as a controller against $L$. sulcigena. Testing these hypotheses is the main aim of this study. 


\section{Material and methods}

\section{Laboratory measurements}

In the following experiments the disease characteristics were assessed from cut shoots in the laboratory. The needles were removed from the shoots and the number of needle scars was counted. In addition, the stage of the disease, the number of needles with $L$. sulcigena ascocarps, and the amount of needles with $H$. acicola were counted for every shoot. The disease severity was defined as the relative number of currentyear short shoots infected by L. sulcigena of the total number of short shoots of the same age. A short shoot was considered diseased when one or both of its needles were infected by L. sulcigena. A healthy short shoot should have two healthy needles. The needles were considered to have ascocarps of $L$. sulcigena if they were a) reddish-brown in the autumn or b) hysterothecial in the spring-early summer. The amount was calculated in relation to all needles infected by $L$. sulcigena. The needles with $H$. acicola were a) greyishgreen or grey in the autumn and b) had no ascocarps of $L$. sulcigena in the spring-early summer. Prematurely shed needles were considered to be affected by $H$. acicola, because needles with ripening ascocarps remain tightly attached to shoots until sporulation (Jalkanen 1985).

The occurrence of $H$. acicola during the Lophodermella epidemic was monitored at Kekälinen, Multia, and at Kaihuavaara and Juotas in Rovaniemi to clarify variations in the amount of $H$. acicola and its effect on the fruiting of $L$. sulcigena (for Finnish locality names, see Jalkanen 1986b). A total of 26 trees having grey needles partly covered by conidia of $\mathrm{H}$. acicola were labelled in the autumn 1980 in a 6-year-old plantation at Kekälinen. There had been abundant Lophodermella needle cast during the two preceding years in the plantation. From all trees a shoot of the second highest whorl was cut in May 1981, 1982 and 1984 and in September 1981 for ascertaining the number of needles infected by $H$. acicola and needles with ascocarps of $L$. sulcigena. Additional notes on the disease in the years 1979-1984 are based on Jalkanen $(1985,1986 \mathrm{a})$.

The abundance of $H$. acicola was recorded also at Kaihuavaara and adjacent Juotas, where four shoots were cut at half-metre intervals from 1 to 5 metres above the ground. Ten diseased trees were sampled in this way at Kaihuavaara in late autumn of 1983, 1984 and 1985 and nine trees at Juotas in June 1985 in order to see the distribution of the disease and especially $H$. acicola in different parts of the tree. All experimental trees were taller than the highest sampling level: the biggest trees reached a height of ten metres.

The relationship between $H$. acicola in autumnal needles and the fruiting of $L$. sulcigena in the follow- ing season was studied at Kaihuavaara, Rovaniemi and at Ii. In October 1983 six infected trees of an average disease severity of $82.5 \%$ were chosen at the Kaihuavaara plantation. The trees had short shoots both with and without $H$. acicola (Jalkanen 1985) in their lower branches. From 35 shoots all the short shoots with $H$. acicola were removed, and the short shoots without $H$. acicola were left. In the other 34 shoots the short shoots without $H$. acicola were removed. The marked shoots were cut the following May to estimate the number of ascocarp-bearing needles.

The same experiment was repeated at Ii in September 1984 with two trees, one which had been suffering from the disease for a 5-year period and another for one year before. From the former (disease severity $49.7 \%$ ), 31 shoots fully infected with $H$. acicola were labelled from the height of 1 to $1.5 \mathrm{~m}$. In the latter tree (disease severity $75.4 \%$ ), 21 shoots without $H$. acicola were labelled at the height of 2 to 3 metres. Shoots were cut in May 1985 to count the number of needles with ascocarps.

A series of biological control experiments on $H$. acicola was carried out at the end of August and at the beginning of September 1984 at Juotas. The experimental stand consisted of 3-7 m high pines on which the Lophodermella epidemic appeared in 1979 and occurred in abundance thereafter. For each experiment six trees having an equal disease severity were chosen. In every tree 15 shoots were labelled at the height of 1-2 metres: five were treated with $H$. acicola, five without (healthy shoot, healthy short shoot or distilled water), and five were left untreated.

The following $H$. acicola inocula were applied:

1) All reddish-brown needles of the shoots were dipped into the conidial suspension in the test tube.

2) Spraying with conidial suspension.

3) Short shoot inoculum: shoots with black pycnospore plates were bound with tape beneath the reddish-brown short shoots, 20 'tape needles' per tree, divided a mong 4 shoots.

4) Shoot inoculum: shoots abundantly infested by $H$. acicola (pycnospores on the needles) were bound beneath the diseased shoots.

The conidial suspension was made from diseased shoot needles having more pycnospore plates by soaking them in water. To test the pathogenicity of $H$. acicola, 20 shoots of 6 healthy trees were treated with each inoculum. The whole experimental series was checked at the end of June 1985.

The control of Lophodermella needle cast by felling diseased pines was tried at Juotas. Four trees per day were felled on August 25, October 15, and November 15, 1984 and January 15, March 15, April 30, and May 31, 1985. The felled trees were placed in a small clearing covered by various amounts of snow during the winter. The occurrence of ascocarps on the felled 
Table 1. The disease severity and the relative amount of Hendersonia acicola on needles of 26 trees infected primarily by Lophodermella sulcigena at Multia: Kekälinen. The plantation established in 1973 was heavily infected by L. sulcigena in 1978-1980. In the autumn 1983 the stand was considered healthy, although single diseased needles existed.

\begin{tabular}{|c|c|c|c|c|c|c|}
\hline \multirow[b]{2}{*}{ Date } & \multicolumn{2}{|c|}{$\begin{array}{c}\text { Disease } \\
\text { severity, } \\
\%\end{array}$} & \multicolumn{2}{|c|}{$\begin{array}{c}\text { or with ascocarps of } \\
\text { L. sulcigena } \\
\%\end{array}$} & \multicolumn{2}{|c|}{$\begin{array}{l}\text { with } \\
\text { H. acicola } \\
\%\end{array}$} \\
\hline & $\overline{\mathrm{X}}$ & $\mathrm{S}$ & $\bar{x}$ & S & $\overline{\mathrm{X}}$ & $\mathrm{S}$ \\
\hline May 1981 & 94.5 & 4.2 & 3.8 & 5.3 & 96.2 & 5.3 \\
\hline September 1981 & 7.0 & 2.9 & 3.1 & 5.8 & 96.9 & 5.8 \\
\hline May 1982 & 6.8 & 2.9 & 16.6 & 18.3 & 83.5 & 18.2 \\
\hline May 1984 & 27.3 & 11.8 & 90.7 & 8.9 & 9.3 & 8.9 \\
\hline
\end{tabular}

trees was checked at the end of June 1985.

The classification of needles is that of Jalkanen (1985). In addition to the needle colour, brittleness is an important feature. In special cases needle fragments were inoculated using $1 \%$ malt extract agar.

\section{Results}

Spatial distribution of $\mathrm{H}$. acicola and its effects on L. sulcigena

The first notes on the Lophodermella epidemic at Kekälinen, Multia date back to August 1978. However, $H$. acicola was not found at that time, but it appeared in October 1979 and again in May 1980. The fungus was very common in September 1980, when the systematic check of the plantation was started. Many trees displayed grey current-year needles. In May 1981 the amount of needles infected secondarily by $H$. acicola reached $96.2 \%$ of the current-year needles infected primarily by L. sulcigena. Developing hysterothecia were seen in only $3.8 \%$ of the diseased needles (Table 1). In spring 1981, when a heavy Lophodermella epidemic had lasted three years, $\mathrm{H}$. acicola had infested nearly all the current-year needles.

Although the summer of 1981 was cold and rainy (favouring needle cast pathogens), only $7 \%$ of the new needles were infected. In the autumn of $1981, H$. acicola had still infected the majority of the new needles, but in following spring the amount of hysterothecial needles rose to one sixth of all diseased needles. During a weak infection diseased needles were found uniformly throughout the shoots and trees. In the autumn of 1982, the plantation was nearly healthy again, despite the fairly cold and rainy summer of 1982. Some hysterothecial needles were found in spring 1983. Possibly due to these ascocarps and the low incidence level of $\mathrm{H}$. acicola, the Lophodermella epidemic reappeared in the summer of 1983.
Now $H$. acicola was present in abundance. The disease severity was as high as $27.3 \%$. Of all the needles infected by $L$. sulcigena $90 \%$ produced ascocarps for the summer of 1984 , and $H$. acicola had infected only about $9 \%$ of needles (Table 1).

L. sulcigena spread to Lapland mainly in the early 1980s. The Lophodermella needles from Kaihuavaara were not infected by $\mathrm{H}$. acicola until the summer of 1981. The disease was severe in 1981-1984. H. acicola was present all the time, but its amount varied.

In the autumn of 1983 the disease was very heavy: $81.3 \%$ of the current-year needles were infected by $L$. sulcigena. The abundance of the disease did not vary statistically significantly along the height of the tree (Fig. 1, line A). On the contrary, the amount of $H$. acicola decreased abruptly towards the upper canopy (Fig. 1, line D). The highest amounts of $H$. acicola (54-60\% of all diseased needles) were below the height of $2.5 \mathrm{~m}$. The amount of H. acicola was at its lowest $(4-10 \%)$ at $4-5$ metres above the ground. The top parts (above $5 \mathrm{~m}$ ) of the canopy remained unstudied. The differences between the amounts of $H$. acicola were highly significant $(\mathrm{F}=7.02$; d.f. $=$ 8/79).

The more common $H$. acicola was in the lower branches, the more common it was in the upper parts of the tree (Fig. 3). The heavy infection level stayed below 3 metres in trees with the highest amount of $H$. acicola. Above it the amount of $\mathrm{H}$. acicola diminished rapidly. Although both the disease severity and the amount of $H$. acicola varied widely between trees, the diseased needles of all trees were almost free of $H$. acicola at the highest $(5 \mathrm{~m})$ level.

The plantation of Kaihuavaara was clearly healthier in the autumn of 1984 than the year before. Still, all of the trees had the uniformly high disease severity of $57.1 \%$. Most recovery was seen in the lowest parts of trees (Fig. 1, line B). Differences between the disease severities during 1983 and 1984 were statistically 

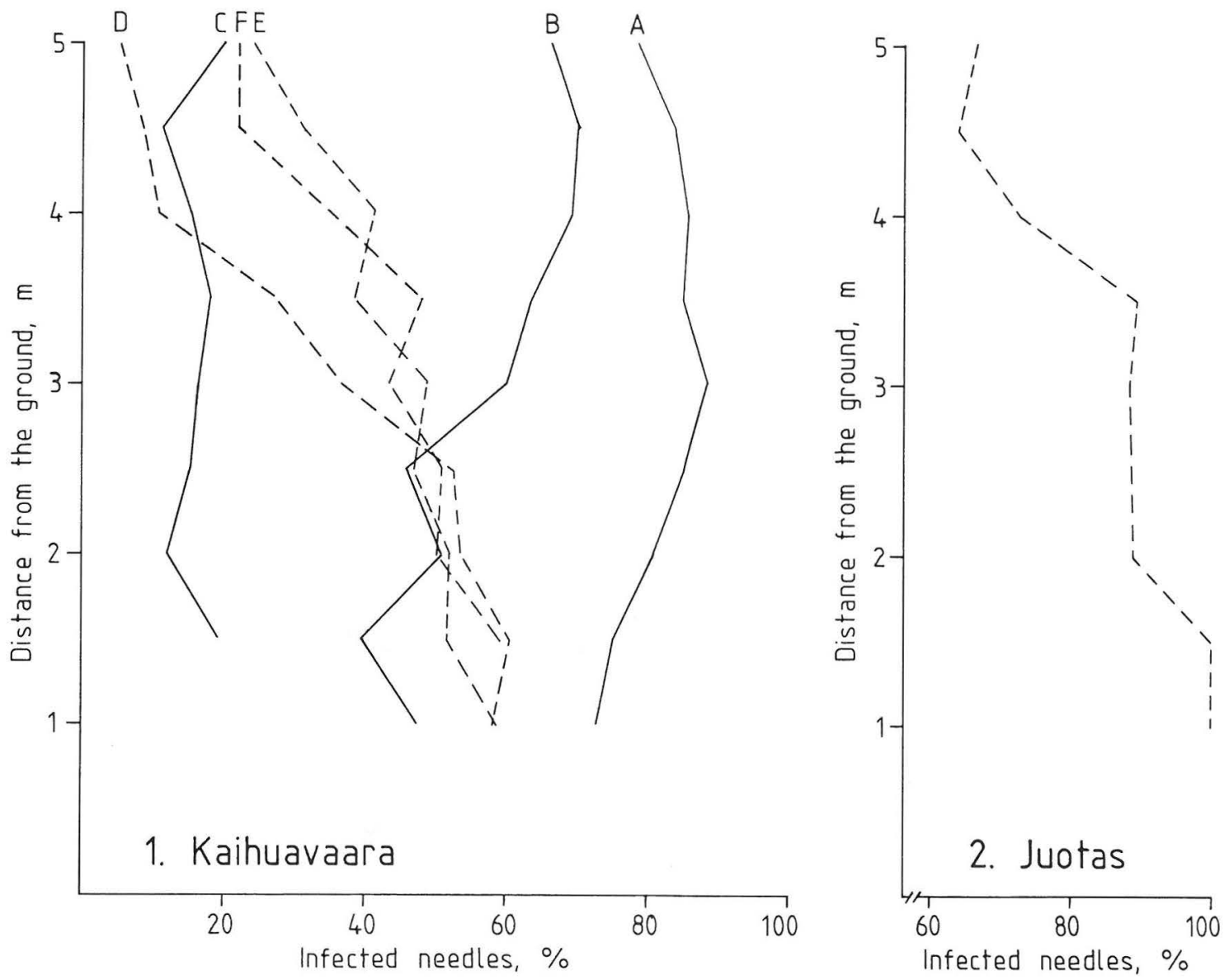

Figs. 1-2. Disease severity (solid line) and the relative amount of Hendersonia acicola (broken line) at different heights of ten pines in the autumn 1983 (A and D), 1984 (B and E) and 1985 (C and F) at Kaihuavaara and in June 1985 at Juotas.

significant at the heights of $1-2.5 \mathrm{~m}(\mathrm{p}<0.001)$ and $3-4 \mathrm{~m}(\mathrm{p}<0.01)$. The recovery above 4 metres was not significant.

Although the disease severity in a stand or even a tree varies annually (Jalkanen 1986b), the alterations in disease severity between 1983 and 1984 were clearly different in the lower $(1-3 \mathrm{~m})$ than in the upper (3.5$5 \mathrm{~m}$ ) canopy. The more common H. acicola had been a year before, the faster the recovery was (Fig. 4).

The amount of $H$. acicola differed between the autumns of 1983 and 1984. The average amount of $H$. acicola rose $8.6 \%$ a year, reaching $46.5 \%$ in the autumn of 1984 (Fig. 1, line E). In the lowest branches, where the recovery had been best, the relative amount of $H$. acicola did not rise. On the contrary, in the upper canopy $H$. acicola became more abundant. H. acicola was most common at the height of $4 \mathrm{~m}$ and was now 4 times more prevalent than the year before. In one year the differences between the lower and upper canopy had disappeared.

In the third year of the study (autumn 1985) the disease had diminished considerably throughout to approx. $10.3 \%$, and no altitudinal differences in the crown were found (Fig. 1, line C). The average amount of $H$. acicola had decreased by $6.4 \%$ from the preceding year nearly to the level of 1983 , and the variation at different heights was insignificant. From autumn 1983 to autumn 1985 the relative amount of H. acicola had changed statistically significantly only at the heights of $4-5 \mathrm{~m}$.

Height comparisons at Juotas in June 1985 showed $H$. acicola to be very common. Only $18.2 \%$ of diseased needles had maturing ascocarps of L. sulcigena, and the rest were infected by $H$. acicola. In the lowest branches of some trees $H$. acicola had infected all the diseased needles (Fig. 2). Also in this stand H. acicola 


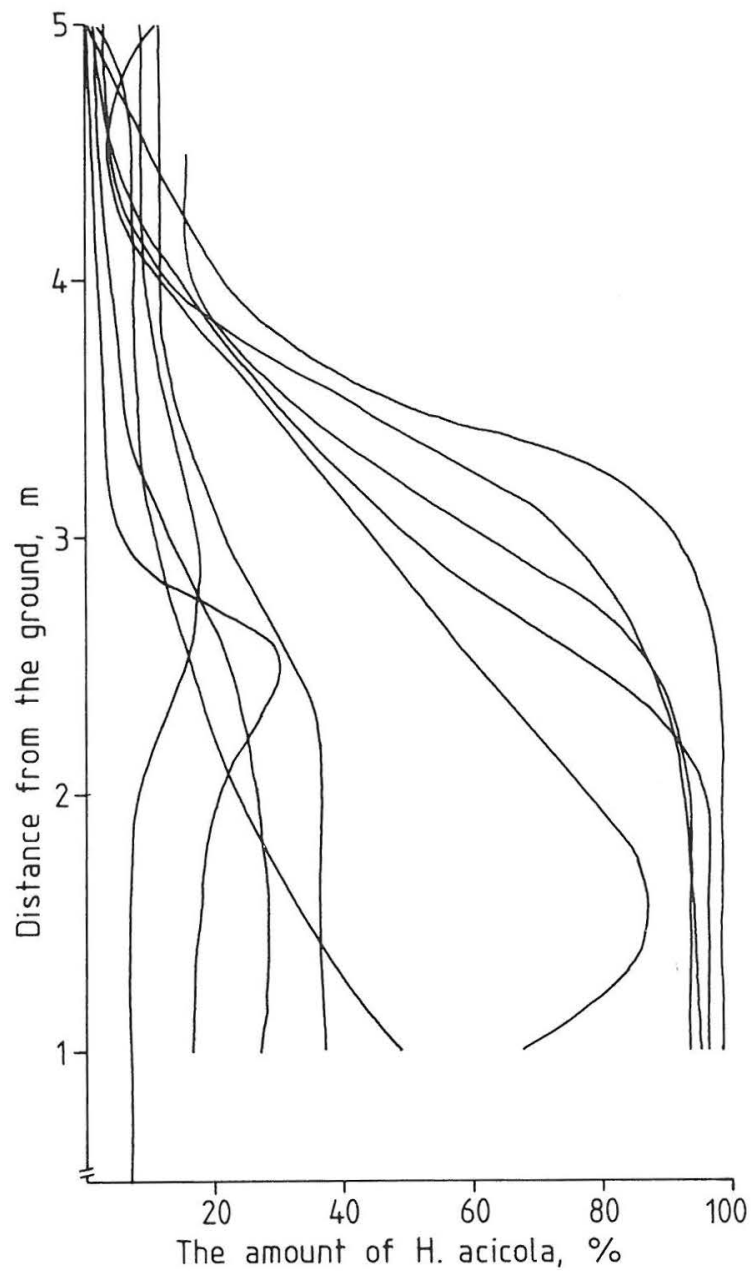

Fig. 3. The amount of Hendersonia acicola at different heigints of ten separate pines at Kaihuavaara in the autumn 1983.

was least common $4-5 \mathrm{~m}$ above the ground v.s. at lower heights $(\mathrm{p}<0.001)$.

When testing separately the effect of natural autumnal secondary infections by $H$. acicola on the fruiting of the primary pathogen, almost total prevention in ascocarp production was seen in both Kaihuavaara and Ii (Table 2). If $H$. acicola was absent from the needles in October, L. sulcigena produced ascocarps in $77.6 \%$ (Kaihuavaara) to $42.3 \%$ (Ii) of them.

L. sulcigena was isolated regularly from reddishbrown needles. $H$. acicola was detected in only one needle in ten. All grey needles contained $H$. acicola. Unknown sterile mycelium was found in two out of ten needles. All grey needles had $H$. acicola. In three out of ten cases Sclerophoma pithyophila (Cda) Höhn. was isolated.

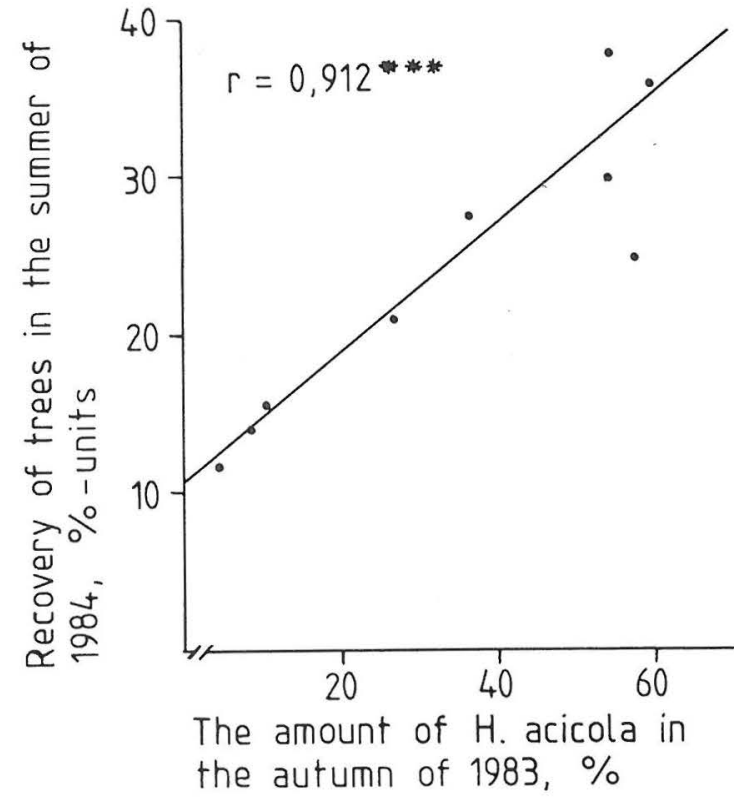

Fig. 4. The correlation between the amount of Hendersonia acicola in the autumn 1983 and the recovery of the trees in the following autumn at Kaihuavaara.

Effect of H. acicola on the fruiting of L. sulcigena

Spraying shoots with a conidial suspension did not add protection (ascocarps in $12.3 \%$ of diseased needles) as compared to no treatment $(14.2 \%)$ or to spraying with water $(9.2 \%)$. On the contrary, the dipping of needles into conidial suspension lowered the ascocarp production of $L$. sulcigena at a level of $\mathrm{p}<0.1$ : The number of ascocarpic needles was $3.4 \%$ v.s. $13.5 \%$ (needles with water treatment) or $8.3 \%$ (untreated shoots). In the shoot inoculum test, the treatment with $H$. acicola was also slightly $(\mathrm{p}<0.1)$ more effective $(0.4 \%)$ than treatment with healthy shoots $(2.2 \%)$ or with no treatment $(4.3 \%)$. The relative natural amount of $H$. acicola was highest in this experiment of all control experiments. The average disease severity in the experiments varied between $74.2-84 \%$. The best result with no ascocarp production was achieved by a short shoot with conidia of $H$. acicola. Also treatment with a healthy short shoot affected the ascocarp production (ascocarps in $2.2 \%$ of needles) more detrimentally to a statistically significant degree $(\mathrm{p}<0.05)$ than no treatment $(33.9 \%)$.

Combining the results of experiments with known disease severities (the dipping of needles and the spraying of shoots with conidial suspension and the use of shoot inoculum) gave mean ascocarp production of $5.4 \%$ in $H$. acicola treatments, $8.3 \%$ in water 
Table 2. The dependence of ascocarp production on the autumnal presence of Hendersonia acicola in the needles infected primarily by Lophodermella sulcigena at Kaihuavaara and Ii.

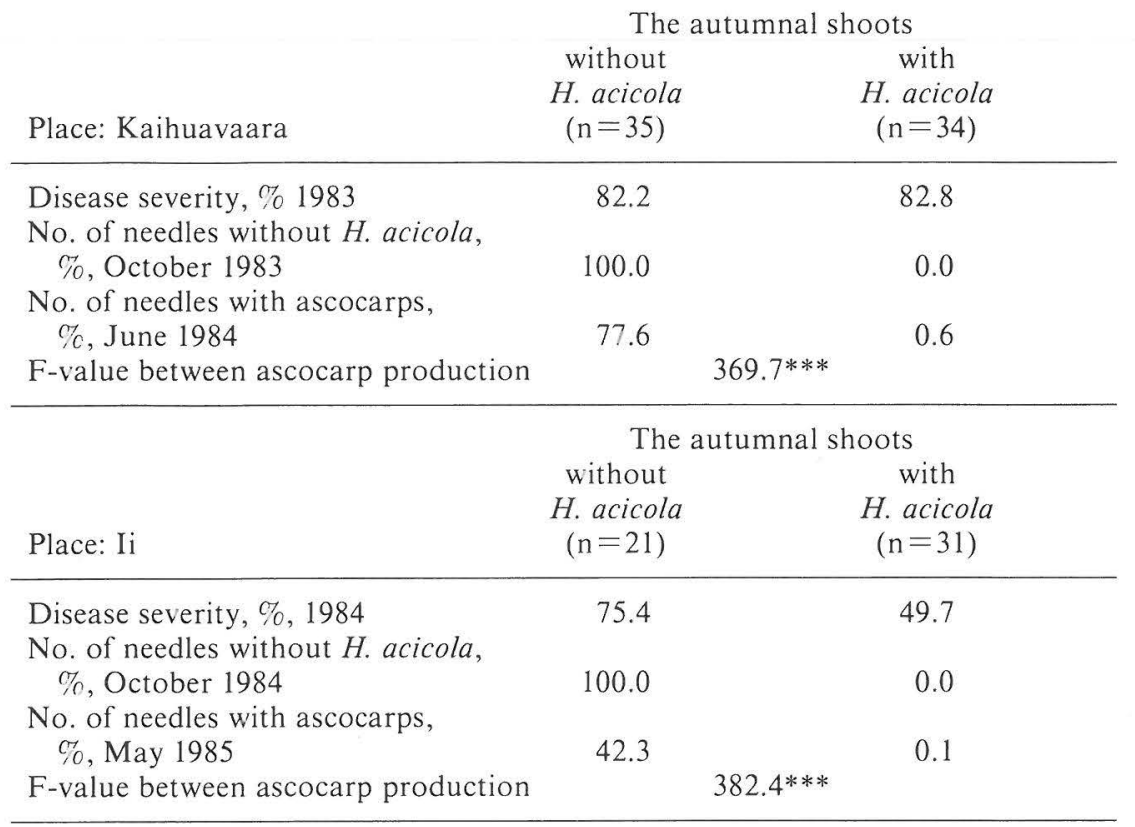

or shoot treatments and $8.9 \%$ in untreated needles or shoots. These differences were insignificant.

Treatments of trees separately with the four inocula of $H$. acicola mentioned above had no visible effects on healthy needles and shoots.

\section{Mechanical control of}

Lophodermella needle cast

No traces of developing ascocarps were found in late June on diseased needles of trees which were felled before November of the preceding year. On pines felled during November-April the pathogen had developed some immature hysterothecia, which were mainly only sets of mycelium. Only in trees not cut until the end of May did the pathogen develop hysterothecia with asci and spores. Diseased needles with ascocarps were found in fewer than $10 \%$. However, the ascocarp amount corresponded to that of trees in control experiments carried out simultaneously in the same stand. The ascocarps could not yet open at the end of June, but the germination of the ascospores was not tested.

Secondary colonisers were abundant on needles of all cut pines. The commonest of them was Leptostroma pinastri Desm. Conidial plates of $H$. acicola on needles were seen only in trees felled in May.

\section{Discussion}

H. acicola proved to be a very common secondary coloniser in the needles primarily infected by $L$. sulcigena. It was harmless to healthy green needles and thus the dependence of $H$. acicola on the primary pathogen (mentioned e.g. by Darker 1967) became confirmed. The connection between other Hendersonia and Lophodermella species has also demonstrated (Czabator et al. 1971, Staley \& Bynum 1972).

Although $H$. acicola depends on the needles infected by $L$. sulcigena, it does not, however, seem to be a hyperparasite. Both fungi can grow on agar without forming barriers to each other (Jalkanen, unpubl.). According to Kranz (1981), most hyperparasites are rusts growing slowly or not at all on an agar medium, while $H$. acicola grows and sporulates well on it (Watson 1971). Also H. acicola lacks the characteristic of hyperparasites whereby they fruit mainly on fruit bodies of the pathogen: it did fruit well on needles without ascocarps of $L$. sulcigena. It can also grow without any substance originating from the pathogen or its host (Jalkanen, unpubl.). However, the observed dependence is still suspected to be based on some compounds of the pathogen. Mitchell et al. (1976b) have observed that cells of $L$. sulcigena are vacuolisated in the vicinity of $H$. acicola and can even lose their contents, which indicates an antagonistic effect. 
On the other hand, some results show that the mycelia disintegrate (Williamson et al. 1976), which might make metabolic products available to $H$. acicola.

Our results confirm the fact already demonstrated in Scotland (Mitchell 1976b) and Finland (Jalkanen 1985), that needles infected by $H$. acicola can easily be recognized by the unaided eye as early as in the autumn of the infection year. Due to the long growth period in Scotland and partly to the infection time, the main early symptom of $H$. acicola (the greyness) does not become visible before October, while in Finland it emerges in August.

When needles were naturally infected by $H$. acicola in the autumn, L. sulcigena could not develop ascocarps. Mitchell et al. (1976b) mention the early secondary infection of $H$. acicola, which occurs in the autumn. It may happen soon after the penetration of L. sulcigena into the needles, in June-August in Finland (Jalkanen 1986b). When no natural infection by $H$. acicola had occurred in the autumn, the needles produced many ascocarps.

The more years the Lophodermella epidemic lasted, the more common $H$. acicola became; present observations support Jalkanen's (1985) statement that an epidemic caused by $L$. sulcigena cannot continue in a tree or a stand more than 3-4 years. An important reason for an epidemic ending seems to be $H$. acicola, which becomes more widespread over the years. Finally, it prevents the pathogen from fruiting, and $L$. sulcigena cannot complete its life cycle.

Pycnospores of $H$. acicola may be relatively heavy, judging by the slow spread of the fungus in a stand or within a tree. This was supported by the scantiness of $H$. acicola in the upper crown in the beginning of an epidemic. Another explanation for the sparse occurrence of $H$. acicola in the top would be unfavourable environmental factors which hinder the establishment of the imperfect fungus. On the other hand, the same factcrs are known to be unfavourable to pathogens causing needle diseases, too. However, the amount of the disease did not vary altitudinally until $H$. acicola had caused some recovery in the lower crown. Difficulties in spread may also explain the differences in the amount of $H$. acicola between neighbouring trees - although they were equally affected by the pathogen - and the sharp fall in the amount of $H$. acicola towards the end of the epidemic. In other words, as the shoots after the tree's recovery have only few needles infected by $L$. sulcigena, it is not so easy for $H$. acicola to reach all the diseased needles. This means an increase in the amount of ascocarps and a revival of the suppressed epidemic. This sequence was evident both in Halkivaha and Multia. However, at the time of new outbreak $H$. acicola is present in all parts of the stand, and the secondary epidemic will be short. For H. acicola it is important that the pathogen can maintain at least a small population for the inter- action between $L$. sulcigena and $H$. acicola to continue.

According to the results the autumnal amount of $H$. acicola had a high negative correlation with the fruiting of L. sulcigena. Also this showed the capability of $H$. acicola to prevent $L$. sulcigena from producing ascocarps.

Relative humidity is very important to the infection of needle cast fungi. Regardless of the humidity there are at the same time some trees in the stand in which the disease advances and others which are recovering (Jalkanen 1986b). The differences in recovery are partly of genetic origin, but many features cannot be explained in any other way than by the influence of H. acicola. For instance, in distant plantations (Loppi, Multia, Rovaniemi) the development was similar but the epidemical time was quite different. The later recovery of trees in Lapland was due to the later beginning of the epidemic there as compared with southern Finland. The epidemic of $L$. sulcigena stopped at Multia in the cold and rainy summer (Anonymous 1982) of 1981, yet in Lapland the Lophodermella needle cast epidemic was advancing (Jalkanen 1985). It is concluded that an epidemic, once it has started, does not easily cease even in a dry summer unless $H$. acicola has become abundant enough to stop it. Secondly, the climatic factors are more important for the beginning than for the cessation of the epidemic.

The end of the Lophodermella needle cast epidemic could be promoted by the distribution of $H$. acicola: this might offer a biological control method against L. sulcigena. Our results imply that the fruiting of the pathogen is naturally decreased by $H$. acicola and can further be diminished by artificially adding $H$. acicola. However, the experiments of control with $H$. acicola did not give as good results as were expected. The main reason for the low control effect was the long duration of the epidemic. In the course of it $\mathrm{H}$. acicola had spread naturally enough to disturb the experiment. There was only a slight possibility to artificially add to the already high level of $H$. acicola. In this case the experiments should have been carried out high in the canopy because the needles at the height of 5-6 m were free of $H$. acicola in the autumn, but produced ascocarps of L. sulcigena. Another suitable place for control experiments would be in the lower branches of trees, on which the Lophodermella needle cast epidemic had just come out.

The spraying with conidial suspension was an unexpectedly uneffective control method. On the contrary, the infection source attached beneath the shoots gave better results than spraying. The infection source in the suspension has been found to be a poor method when using the pathogen (L. sulcigena) itself (Millar 1984). When the source of $H$. acicola stays long beneath the needles, there is better proba- 
bility for a favourable weather to occur. If the conidia are sprayed, rain can wash them away, or a dry period can prevent their germination or penetration. Using shoot or needle inoculum, new conidia can easily be deposited on the needle after every dry period.

The effective needle inocula were probably due to the humid conditions developing inside the tape seal, which are like those in a growth chamber. Success even with only a short shoot inoculum points towards a better climate for germination.

To remove single infection sources, the felling of the trees before May is enough to prevent L. sulcigena from maturing the ascocarps. Further hygiene by burning the branches, recommended by Terrier (1944), is hardly needed. In spore trapping experiments (Jalkanen, unpubl.) the ascocarps of shoots placed in a water pail behaved abnormally in the rain only 2 weeks after being cut (cf. Jalkanen 1986b).

Further experiments are needed on how to expose the needles more easily to $H$. acicola. Regardless of the inconclusive results obtained here, the spraying method should be developed further because of its wide availability for use. A conidial suspension could be spread quickly and easily from the air on large areas and especially on older plantations. Aerial spraying would also infect the upper crown, which could then serve as an infection source to lower branches. It is evident that a successful control could shorten the Lophodermella epidemic by 2-3 years.

Hendersonia species are known to sporulate easily in the laboratory (e.g. Barnett \& Hunter 1972). $H$. acicola sporulates in four weeks on malt extract agar and in two weeks on needle extract agar (Watson 1971). For a large scale control of the Lophodermella needle cast the production, storing and spread of $H$. acicola should be examined.

\section{References}

Anonymous 1982: Kuukausikatsaus Suomen ilmastoon. Yhteenveto 1981. - Ilmatieteen laitos. Helsinki.

Barnett, H. \& Hunter, B. 1972: Illustrated genera of imperfect fungi. 3rd ed. -241 pp. Minneapolis.

Czabator, F., Staley, J. \& Snow, G. 1971: Extensive southern pine needle blight during 1970-71, and associated fungi. - Plant Dis. Rep. 55: 764-766.

Darker, G. 1967: A revision of the genera of the Hypodermataceae. - Canad. J. Bot. 45: 1399-1444.

Jalkanen, R. 1981: Harmaakariste männyllä. Kirjallisuuskatsaus. Abstract: Lophodermella sulcigena on pines. A literature review. - Folia For. 476: 1-15.

- 1982: Lophodermella sulcigena in clones and progenies of Scots pine in Finland. - In: Heybroek, H., Stephan, B. \& von Weissenberg, K. (eds.), Resistance to diseases and pests in forest trees. Proc. Third Int. Workshop on the Genetics of Host-Parasite Interactions in Forestry, Wageningen, the Netherlands, 14-21 Sept. 1980: 441447. Pudoc.
- 1985: The occurrence and importance of Lophodermella sulcigena and Hendersonia acicola on Scots pine in Finland. - Karstenia 25: 53-61.

- 1986a: Tiedot männynharmaakaristeen (Lophodermella sulcigena) ja sen yhteydessä esiintyvän Hendersonia acicola -sienen esiintymisestä Suomessa. Summary: List of records of Lophodermella needle cast incl. Hendersonia acicola in Finland. - Metsäntutkimuslait. tiedonantoja 234: 1-9.

- 1986b: Lophodermella sulcigena on Scots pine in Finland. Seloste: Männynharmaakariste Suomessa. Comm. Inst. For. Fenn. 136 (in print).

Kranz, J. 1981: Hyperparasitism of biotrophic fungi. - In: Blakeman, J.P. (ed.), Microbial ecology of the phylloplane: 327-352. London.

Lagerberg, T. 1910: Om gråbarrsjukan hos tallen, dess orsak och verkningar. - Medd. Stat. Skogsförs. Anst. 7: 127174.

Millar, C. 1970: Role of Lophodermella species in premature death of pine needles. - Rep. Forest Res. (London) 1970: 176-178.

- 1984: Lophodermella species on pines. - Proc. IUFRO S2.06.04 Needle Disease W.P., Gulfport, Miss., U.S.A., Oct. $1984.31 \mathrm{pp}$.

Mitchell, C., Millar, C. \& Haworth, M. 1976a: Effect of the needle-cast fungus Lophodermella sulcigena on growth of Corsican pine. - Forestry 49: 153-158.

Mitchell, C., Williamson, B. \& Millar, C. 1976b: Hendersonia acicola on pine needles infected by Lophodermella sulcigena. - Eur. J. For. Path. 6: 92-102.

Roll-Hansen, F. 1969: Soppsykdommer på skogtraer. - 144 pp. Vollebekk.

Staley, J. \& Bynum, H. 1972: A new Lophodermella on Pinus ponderosa and P. attenuata. - Mycologia 64: 722-726.

Terrier, C. 1944: Über zwei in der Schweiz bisher wenig bekannte Schüttepilze der Kiefern: Hypodermella sulcigena (Rostr.) Tub. und Hypodermella conjuncta Darker. - Phytopath. Z. 14: 442-449.

Watson, A. 1971: Fungi causing premature needle cast of Pinus sylvestris L. - Doctoral Thesis, Dept. For., Univ. Aberdeen. 116 pp +3 appendices. Aberdeen.

Accepted for publication

on April 2, 1986 